\title{
Acceptability and marketability of the developed Madhubani shawls
}

\author{
RUPAL BABEL AND CHETNA CHOUHAN
}

Received: 22.05.2017; Revised: 09.10.2017; Accepted: 23.10.2017

See end of the paper for authors' affiliations

\section{RUPAL BABEL}

Department of Textiles and Apparel Designing, College of Home Science, Maharana Pratap University of

Agriculture and Technology, UDAIPUR (RAJASTHAN) INDIA

Email : babelrupa166@gmail.com
ABSTRACT : The present study explores the possibility of development of shawls through hand painting using Madhubani Motifs. The objective of present study was to assess the acceptability and marketability of developed shawls using Madhubani motifs. The study results revealed that developed products were highly appreciated by all the respondents. The most preferred shawl was $\mathrm{S}_{5}$ with first rank. Acceptability range of all the products ranged from 77 per cent to more than 83.83 per cent. Cost of all products ranged between Rs. 685 to Rs. 730 .

KEY WORDS: Madhubani painting

-HOW TO CITE THIS PAPER : Babel, Rupal and Chouhan, Chetna (2017). Acceptability and marketability of the developed Madhubani shawls. Asian J. Home Sci., 12 (2) : 466-468, DOI: 10.15740/HAS/AJHS/ 12.2/466-468. 